\title{
IMPACT OF EASTERN PARTNERSHIP INITIATIVES ON EUROPEANIZATION PROCESSES IN UKRAINE
}

\author{
Vadym Zheltovskyy, PhD \\ University of Warsaw, Faculty of Political Science and International Studies, Poland \\ v.zheltovskyy@uw.edu.pl
}

\begin{abstract}
The article analyses the impact of Eastern Partnership initiatives on the Europeanization processes in Ukraine. Particular attention is paid to the external Europeanization and the Europeanization ad personam in context of bilateral relations between the European Union and Ukrainian authorities. In order to follow the implications of the external Europeanization from the perspective of institutional dimension, the paper underlines the essence of Eastern Partnership instruments and initiatives aimed at the enhancement of cooperation among the partner states and at the engagement of civil society actors into the policy-making process. Furthermore, the accent is put on the issue of Eastern Partnership and European integration in political discourse of Ukrainian presidents. The comparative analysis of presidential rhetorical strategies gives opportunity to study the evolution of ad personam dimension of the Europeanization process in Ukraine and analyse the connection between rhetorical messages and future format of EU-Ukraine cooperation
\end{abstract}

Keywords: Eastern Partnership, Ukraine, external Europeanization, Europeanization ad personam.

\section{Introduction}

The Eastern Partnership (EaP) initiative has been functioning for more than ten years which gives ground to reflect on the first outcomes of undertaken steps in partner states participating in given project. In fact, it is Ukraine that has proved to be an active beneficiary of the EaP programme since 2009. Therefore, the paper analysis covers selected case studies of the external Europeanization and the Europeanization ad personam processes in Ukrainian state. The purpose of the article is twofold: 1) to define the major outcomes of the external Europeanization processes in Ukraine, and 2) to explain the effects of Europeanization ad personam in context of the cooperation between the EU and Ukrainian authorities in the analysed period of years 2009-2020. 
The following research questions have been formulated with the view to reaching the purpose stated above:

1. What were the main policy areas supported by the European Union (EU) in terms of the EaP initiative?

2. How did the institutional dimension of the external Europeanization evolve in terms of the EaP project?

3. What are the major mechanisms of cooperation between political and civil actors in terms of the EaP actions in Ukraine?

4. Were effects of Europeanization ad personam reflected in presidential discourse in Ukraine?

The article attempts to verify the main hypothesis stating that the EaP format has created working platforms for cooperation between political and civil actors leading to important systemic solutions aimed at the Europeanization of the governance in Ukraine. Meanwhile, the quality of the EU-Ukraine relations will directly depend on their commitment to further development of the efficient bilateral format of such cooperation and on the effectiveness of the Europeanization ad personam addressed to political and civil actors engaged in the democratic transformation of Ukraine.

As far as the conceptual framework is concerned, the research is based on the concepts of the external Europeanization and the Europeanization ad personam that are understood, on the one hand, as a transfer of European norms and regulations aimed at the transformation of Ukrainian institutions and system of governance, and, on the other hand, as the EU impact on particular political and civil actors who are actively engaged in the transformation processes in Ukraine. The Europeanization ad personam is analysed in order to define its influence on the political leadership of Ukraine with particular emphasis on their approach toward the EU-Ukraine cooperation and future format of such cooperation.

From the methodology point of view, the systems analysis method gives tools to analyse the interaction among all the constituents of particular political system as well as to follow how the changes of one constituent affect the other ones. In terms of the article, the focus is put on the interaction among policy-makers, civil society organisations and scholars as elements of the system. The demands of Ukrainian civil actors to transform system of governance and policymaking tradition in accordance with the EU standards may be considered as the input of the 
political system while adopted legislation and development strategies are regarded as the output. Additionally, the article is based on the comparison method that is used to compare political approach of the Ukrainian presidents toward the European integration in years 2009-2020. Furthermore, the method of critical discourse analysis was implemented in order to discover presidential rhetorical strategies on given matter.

\section{Terminology Conceptualisation and Theoretical Framework of the Research}

Traditionally, the scientific analysis of the Europeanization concept has been mainly concentrated on the internal Europeanization studying either the EU legislation impact on member states (Ruszkowski, 2019), institutional aspect of constant change (Beck and Grande, 2009), major forms of interaction between the EU and member states (Borzel, 2005), or the negotiation process between member states and EU institutions aimed at mutual adjustments (Tosiek, 2018, p. 153). In this regard, Tosiek (2012, p.173) points out to the challenges in the context of the national decision-making process followed by the obtaining of the EU membership relating to further implementation of the reforms implied by the process of membership negotiations, and to the implementation of the EU norms into the internal legal systems of new member states.

At the same time, scholars have emphasised the external character of the Europeanization focusing on its impact on the non-EU states. In his classification of „Europeanization faces”, Olsen (2002, pp. 921-952) defined a transfer of norms and regulations outside Europe as one of them together with territorial expansion of the EU/Europe; institutionalisation on European level; political action aimed at strengthening the integration; or changes of state and regional system of management. Overall, as far as the external Europeanization is concerned, it has a direct connection with the Eastern policy of the EU and the EaP Initiative in particular (Agh 2016, p.37.) Meanwhile the essence of the external Europeanization phenomenon lies in the central role of the EU which transfers its standards, norms and values to neighbourhood states (Cianciara, 2017, 84).

Concerning the Europeanization ad personam, Ruszkowski (2019, p. 203) argues that while studying the issue of Europeanization and its impact on institutions, states or regions, one should take into account its influence on other actors (individual and collective) of given process such as people, social groups, or elites. Therefore, the article focuses on the issue of European integration in presidential rhetoric in order to follow the evolution of the EU impact on political leadership of Ukraine. 


\section{The implications of the external Europeanization - institutional dimension}

Prior to the analysis of the external Europeanization attempts in context of the EaP Initiatives, this part of the article starts with the brief overview of the EU programs and initiatives introduced by the EU before the launch of the EaP. To speed the process of transformation in partner states, the European Commission (EC) created a number of instruments in terms of the European Neighbourhood Policy (ENP). The first attempt was made in 1991 when the EU started its Tacis - Programme ${ }^{1}$. Interestingly enough, it was Kyiv where the programme opened its office for Eastern Europe (Domaradzki, 2014, p. 280). Important aspect was that the main element of Tacis support was aimed at transferring know-how and expertise to organisations in the partner countries. In fact, both governmental and non-governmental organisations could take part in the programme. Furthermore, Tacis was replaced by the European Neighbourhood and Partnership Instrument (ENPI) which introduced such innovative features as:

- $\quad$ cross-border cooperation, which provided ground for joint programs, bringing together regions of Member States and partner countries sharing a common border;

- $\quad$ a Governance Facility which supported creative partners showing the eagerness to reform their regions using good governance strategy;

- $\quad$ the Twinning and the TAIEX instruments that served as a cooperation tool between a public administration in a partner country and the equivalent institution in an EU Member and were aimed at enhancing co-operative activities (European Commission, 2004).

Another instrument initiated by the EC with the view to improving territorial cooperation in the EU was the European grouping of territorial cooperation (EGTC). Regulation 1082/2006 of the European Parliament and of the Council was adopted on 5 July 2006. However, it concentrated mainly on the EU member states allowing regional and local authorities and other public undertakings from different member countries to set up groupings with a legal personality to deliver joint services. EGTCs were recognized as legal entities whose mission was to facilitate cross-border, transnational or interregional cooperation in the EU (European Commission, 2006).

\footnotetext{
${ }^{1}$ Tacis is an acronym for Technical Assistance to the CIS (or Commonwealth of Independent States). The name of the programme was spelt out in capital letters - TACIS- but the name was later changed to "Tacis" to account for its broader range of activities and inclusion of partner states. Source:

http://eeas.europa.eu/delegations/georgia/eu_georgia/tech_financial_cooperation/instruments/tacis/index_en.htm.
} 
One could have observed positive tendencies in the following years as regards prospects for participation for the third countries. One of the most recent changes was proposal of the EC as regards the clarification, simplification and improvement of the establishment and implementation of EGTCs. The document presented threefold philosophy:

1) continuity: no need to change the basic nature of an EGTC, its statutes or ways of operating;

2) clarity: the need to modify the Regulation in accordance with the Lisbon Treaty in order to clarify the confusing aspects and ensure more visibility and communication on the formation and operation of EGTCs;

3) flexibility: opening up EGTCs to any aspect of territorial cooperation and providing legal bases for the participation of authorities and regions from third countries to participate as members (European Commission, 2012).

Despite the initiatives and instruments in terms of the partnership concept introduced by the EU, scholars point out to the cases of unwillingness from the side of neighbouring states to conduct reforms under the existed conditions. As a result, the EC undertook a series of steps to create a form of partnership that would be more appealing to partner states and would engage more civil actors into the process (Korosteleva, 2013, p. 13). It was the EaP Initiative in 2008 aimed at strengthening both the state institutions and civil society organisations in each partner state.

Ukraine officially joined the EaP in 2009. Among key priorities of the Initiative were the following: association with the EU, creation of a Deep and Comprehensive Free Trade Area (DCFTA), dialogue on the establishment of a visa free regime, and energy cooperation. Achieving the above mentioned goals by partner states required the reforms of such spheres as public administration, civil service, civil protection, judiciary, etc. Moreover, reforms in given areas involved the application of appropriate experience from other members of the Partnership (European Council, 2015).

As Tymanowski puts it (2014, p. 111), the EaP was a chance for the improvement of relationship between Ukraine and the EU and for the establishment of joint mechanisms leading to the growing role of European impact on the direction of political vector in Kyiv. Importantly, the project was initiated by Poland and a subsequent proposal was prepared in cooperation with Sweden which resulted in the presentation of foreign ministers of Poland and Sweden at the EU's General Affairs and External Relations Council in Brussels on 26 May 2008. 
As a result, a wide range of the EaP initiatives implemented in Ukraine have contributed to the achievement of the Sustainable Development Goals expressed in the EC Staff Working Document „Key European action supporting the 2030 Agenda and the Sustainable Development Goals" (2016). Particular attention should be paid to Erasmus+ programmes for education development ${ }^{2}$ which may have numerous benefits for young generation of Ukrainians and serve as an effective Europeanization ad personam instrument addressed to future decision-makers. The initiative of equal importance is the PRAVO-JUSTICE project in Ukraine $^{3}$ aimed at providing support for the Ukrainian justice sector.

In terms of the institutional dimension addressed at the top decision-makers in partner states, the EURONEST Parliamentary Assembly was established in 2011. The Assembly created the multilateral cooperation platform for parliamentary dialogue on the issues related to the $\mathrm{EaP}$. Article 5 of the Rules of Procedure defines relations with the EaP Summit, the Council of Ministers, the EC and ministerial conferences stating that the Bureau of the Assembly ${ }^{4}$ is responsible for forging ,closer ties in all areas with the institutions, bodies and organisations of the Eastern Partnership" (EURONEST).

Furthermore, the external Europeanization effects could be seen in context of PolishUkrainian cooperation between regional and local authorities which importance was clearly emphasised by the Committee of the Regions in its official documentation. The example might be the Opinion of the Committee of the Regions on the role of local and regional authorities within the EaP published on 22 April 2009. The paper considered the development of local democracy as a central element in cooperation between the EU and countries from the EaP project (Committee of the Regions, 2009). Such interregional cooperation provided Ukrainian regions with new opportunities for the participation in a range of joint programs and is considered to be beneficial for the regional adaptation to the European standards. Similar cooperation framework may serve

\footnotetext{
${ }^{2}$ More on Erasmus Plus Programme in Ukraine see: https://erasmusplus.org.ua.

${ }^{3}$ More on the PRAVO-JUSTICE project see: https://www.pravojustice.eu.

${ }^{4}$ In accordance with art. 1 Rules of Procedures, ,The two components of the EURONEST Parliamentary Assembly shall elect a Bureau from among their members, consisting of two Co-Presidents of equal status (one belonging to each of the two components of the EURONEST Parliamentary Assembly) and a number of Vice-Presidents (one from each of the participating Eastern European Partners different from the country of the relevant Co-President and an equal number from the European Parliament). The electoral procedures and terms of office shall be decided by each component separately.
} 
as an incentive for citizens encouraging them to actively participate in life of their region through the implementation of the European standards of governance on local scale (Buglay, 2013, p. 81).

Analysts agree that the strong and well organised potential of local and regional authorities improves efficiency of governance and is crucial for successful democratisation. In this regard, empirical experience of self-governments (local, regional, state, European and international) cooperating in a decentralised way with partners in the $\mathrm{EaP}$ are considered to be of primary importance. At the same time, there appeared a need to create common discussion platform in order to receive optimal results and fruitful solutions using diverse experience of a wide range of local actors. Such platform known as Conference of Regional and Local Authorities for the EaP (CORLEAP) was created in 2011 as the political forum of local and regional authorities from the $\mathrm{EU}$ and the EaP countries. CORLEAP is positioned by its initiators as the only EU platform that offers an opportunity to discuss the contribution by cities and regions in the development of the EaP. Being established as a result of common efforts of the EC and the Committee of the Regions, CORLEAP created ground for political cooperation between local and regional authorities in the EU and partners from the EaP. (Zheltovskyy, 2019, p. 121). According to Taczyńska (2013, p. 37), such cooperation would result in the increase of local authorities' impact on regional political strategy development and would strengthen the citizen-official cooperation in partner states that all together would lead to a stronger local government.

In terms of the undertaken steps toward the engagement of civil actors into the Partnership initiatives, the Civil Society Forum was created. Its General Assembly meets annually to debate on the achievements of the EaP Programme and engages various civil society organisations from the EU and partner states. Additionally, each member state has own national platform of the forum that monitors their accomplishments.

It is important to highlight that in accordance with the joint declaration adopted at the 11th annual General Assembly of the Forum, major challenges that impede the implementation of the EaP policy in partner states relate to "modest results in the field of justice reform, which is a key to fighting high-level corruption and holding the governments accountable" (EaP Civil Society Forum, 2019). Similar declaration from civil actors illustrates the positive effects of external Europeanization processes and may work as additional pressure on the decision-makers to foster the reforms aimed at overcoming corruption. 
The case of Ukraine demonstrates that there has been a slow but positive change in the international evaluation of the corruption rate. In this context, Transparency International positioned Ukrainian state on the 120th position out of 180 countries and territories in 2019 which illustrates slow positive dynamics in comparison to year 2013 when Ukraine found itself on 144th position (Transparency International, 2013, 2019). Such dynamics brings ambivalent conclusions on the pace of anti-corruption policies. On the one hand, the EaP initiatives provided policymakers with the tools to launch key reforms directed at overcoming systemic corruption. On the other hand, however, the implementation process was sometimes slow or blocked by officials, and it was pressure of civil society organisations and the EU officials that has led to the positive dynamics in a number of cases (Zheltovskyy, 2020, p. 91).

Similar observations refer to the reforms concentrating on establishing mechanisms for open access to information connected with the state and local budget expenses or functioning of the public servants that have been implemented in 2015-2019 and are supposed to eliminate the risk of abusing power and minimise corruption (Vox Ukraine 2019). In fact, the EU called the law on anti-corruption court adopted by the Ukrainian MPs and signed by President Poroshenko in 2019 "a positive development" and "a significant step" in the fight against corruption, as well as "a key component" of the EU-Ukraine Association Agreement (AA) (eeas.europa.eu, 2019).

In terms of the latest developments in the external dimension of the Europeanization processes, on 18 March 2020 the EC presented the EaP Policy beyond 2020 „Reinforcing Resilience - an EaP that delivers for all”. The document emphasises the positive results achieved in 3 out of 4 priority areas (stronger economy, stronger connectivity and stronger society) adopted in „20 Deliverables for 2020”. As regards the stronger governance priority area, the document argues for "the need to significantly improve results" in the governance sphere connected with anti-corruption efforts and empowerment of civil society. Therefore, the authors of the report recommend introducing changes to the incentive-based approach such as „objective, precise, detailed and verifiable benchmarks" for reform implementation (EC, 2020). Such recommendation, in fact, echoed the conclusions made in the $2017 \mathrm{EaP}$ Report which argued for the stricter conditionality principle meaning that financial support to the respective government should be based on the success of legal reforms aimed at overcoming corruptions in partner states (2017 EaP Index, 2018). 
Concerning the external factors that might determine the EaP partner states cooperation with the EU in the following decade and the Europeanization in Ukraine in particular, the report EaP 2030 Trends names the following: 1) the growing Russian resilience in the region; 2) the EU concentration on efficiency of its actions; 3) ,growing individualisation” of the EaP members; 4) political instability in EaP countries. According to the authors, by creating frozen conflicts, Russia undermines the attempts of such EaP partner states as Ukraine to gain NATO and EU's membership (EaP 2030, p. 6). It is also true that Russian opposition toward the concept of the EaP is a serious impediment to its successful functioning due to Moscow's active involvement in the politics of such partner states as Belarus or Armenia who joined Eurasian Economic Union (Barburska, 2019, p. 160).

Therefore, experts point out to the significance of security aspect for further development of the EaP partner countries (Kruglashov 2020, p. 76) and the importance of concerted efforts to counteract Russian disinformation campaigns in the region. Gahler (2021, p. 6) gives example of the „EUvsDisinfo" project established in 2015. The project tasks include identification, collection and communication about Russian disinformation campaigns in order to protect the EU member states and neighbouring countries. The author asserts that EaP partner states could also benefit from given project and that is why it should be promoted in order to increase their resilience to Russian disinformation campaigns (Gahler, 6).

As for the position of Ukrainian authorities, a vivid example of the attempt to counteract such campaigns was the establishment of Crimea platform as a new initiative aimed at bringing international attention to Russia's illegal annexation of Crimea peninsula. Importantly, the inauguration summit was attended by representatives of 46 states and international organisations who signed the Crimea Platform Declaration calling on Russia to de-occupy the Crimea and to recognise territorial integrity of Ukraine (Joint Declaration, 2021).

Meantime, in reference to the debate on the future form of the EaP, the need to develop a tailor-made approach to particular partner state has been continuously repeated by Ukrainian top official responsible for the integration with the EU. The example of the most recent developments on the matter was the establishment of the „Association Trio" initiated by Ukraine, Moldova and Georgia in May 2021. The idea behind the project is to strengthen the policy coordination in the field of European integration. As the Minister of Foreign Affairs of Ukraine put it, EaP needs „, a strategic update" (Kuleba, 2021). 
The observations mentioned above illustrate that the decision-making process on the EaP initiatives has been differently affected by different actors engaged in the given process and has been determined by both external and internal factors. Due to the dynamic nature of given factors, there is a visible need to further develop the EU's eastern policy with particular focus on strengthening its role in security management and on individual approach to partner states based on their commitment to democratic transformation and progress in given field.

\section{The Europeanization ad personam and its effect on the transformation of the}

\section{Ukrainian political system}

Below there is made an attempt to present the level of political leadership engagement into the $\mathrm{EaP}$ projects and the rhetorical strategies implemented by four Ukrainian presidents. To illustrate the ad personam dimension in terms of the $\mathrm{EaP}$ initiative in Ukraine, the analysis covers the declared position of Ukrainian political leaders toward the transfer of EU norms and regulations.

Due to the fact that strategic communication is regarded by the EC (2020) as a crucial element of „building resilience”, and as ,a core duty for policy-makers at the service of citizens”, this part of the article studies the political speeches of Ukrainian presidents devoted to the EaP in order to follow the level of ad personam engagement into the Europeanization process in the analysed time framework (2009-2020).

In fact, it was the 2014 Revolution of Dignity in Ukraine triggered by the refusal of Viktor Yanukovych to sign the AA with the EU that led to the 2014 early presidential and parliamentary elections in Ukraine and in consequence to the official announcement of its pro-European course.

To remind, Yanukovych tried to avoid announcing a clear pro-European or a pro-Russian course during his stay in power in 2010-2013. Instead, he was sending mixed signals to the EU and to Ukrainians who supported the European integration. Before his infamous decision not to sign the AA with the EU in November 2013 and agreement to accept a significant financial assistance of 3 billion dollars from Russia, Yanukovych declared his plans to integrate Ukraine with EU. In her memoirs, former US Secretary of State Condoleezza Rice argues that Yanukovych was trying to sign the Agreement despite the Russian attempts to block the integration process but his final decision was largely influenced by Russian blocking Ukrainian import to Russian 
Federation in 2012 and declarations of Russian politicians on continuation of similar practices in case of signing the AA with the EU (Rice, 2018, p. 141).

The EU, in turn, failed to convince the Ukrainian governance to finalise the deal that demonstrated a lack of Europeanization ad personam strategy at the time. In fact, the issue of incentives offered by the $\mathrm{EU}$ to the $\mathrm{EaP}$ states proves to be a significant constituent of the Europeanization ad personam process. Lavenex (2007, p. 247) defines three mechanisms available to the EU that can be used in order to encourage non-EU countries to implement policy decisions „in the absence of membership conditionality” including intergovernmental negotiations, transgovernmental networking, and the international organisations. Interestingly enough, according to the joint policy communication published by EC in March 2020, „Civil society organisations are crucial for disseminating EU-positive messages outside of the capitals, and ensuring lasting results and better services for people on the ground". Such observations led to the EU decision to enhance the engagement of key civil society organisations into the policy-making process mentioned above (EC, 2020).

The example of Yanukovych illustrates that while speaking about financial incentives, it is important to analyse the political incentives and the value orientation of certain politicians in the EaP states. Most likely, the decision of Yanukovych could have been influenced not only by the economic incentive from Russia but equally by his set of values and vision of the state development that was always closer to the authoritarian model than to the democratic one.

On the contrary, the declared position of authorities elected in the 2014 democratic elections was clearly pro-European that reflected the position of majority of Ukrainian voters. Political declarations on readiness to introduce European good practices of governance were expressed by such politicians as Petro Poroshenko or Arseniy Yatseniuk whose parties won the parliamentary elections in 2014. Similar declarations were an answer to broad public demand for freedoms and the rule of law. Therefore, the topic of power decentralisation and citizens' empowerment was one of the leading ones in the 2014 election campaign.

Moreover, the decentralisation and self-governance reform in Ukraine has been one of the most fundamental reforms in the post-Euromaidan period that engaged both Ukrainian and foreign political and civil actors (non-governmental organisations, university scholars). In terms of the Europeanization ad personam effect in the context of the decentralisation reform, its impact on the Ukrainian decision-makers is visible on the example of Polish-Ukrainian cooperation on given 
matter in 2014-2019. One could have observed the declarations of top Ukrainian officials in the Post-Euromaidan period on their readiness to implement the self-governance transformation following the example of Polish model of the reform. To name a few examples, during his first official visit to Poland, President Petro Poroshenko asserted that Polish experience in decentralisation reform was the most relevant for Ukraine and it would be taken as a basis during works of Constitutional Committee in Ukraine while then Speaker of Ukrainian Parliament and former Prime Minister of Ukraine Volodymyr Groysman like his predecessor Arseniy Yatseniuk requested Polish government to provide Ukraine with practical advice on self-governance reform (Zheltovskyy, 2016, p. 551).

\section{Europeanization ad personam - case study of presidential rhetoric in Ukraine}

The following part of the article focuses on the issue of European integration and EaP initiatives in political discourse of Ukrainian presidents. The presidential rhetoric is regarded as a political tool aimed at getting support on both domestic and international arenas. In terms of the European integration, it may serve as an efficient instrument for setting the agenda and for raising public awareness on given matter.

Thus, the article's effort to analyse the issue of the EU-Ukraine relations in key presidential messages is expected to present the effects of Europeanization ad personam on the example of Ukrainian leadership as well as disclose the Europeanization prospects in Ukraine.

As a matter of fact, it is presidential inauguration address that is supposed to define the vision of future policy-making inside a particular state and directions of international cooperation, and to declare a certain set of values, norms and expectations in context of the state management. In case of Ukraine, brief analysis of inauguration addresses delivered by four Ukrainian presidents make it possible to compare the emphasis on the issue of Europeanization in presidential rhetoric and explain Europeanization ad personam effects in particular cases.

Firstly, the examples of Viktor Yushchenko and Viktor Yanukovych illustrated the opposite approach to the issue of the EU-Ukrainian cooperation. Viktor Yushchenko, who became the president of Ukraine after the Orange Revolution in 2004, clearly stated that he saw Ukrainian future in the EU and declared it as his foreign policy goal. Among arguments given in favour of such declaration were the following: common values, history, and belonging to the same civilisation (Yushchenko, 2005). Unlike his predecessor, Viktor Yanukovych did not include any 
statements on his plans to integrate with the EU in his inaugural address. Instead, the speech presented the vision of Ukraine as a bridge between the West and the East. Moreover, Yanukovych described Ukraine as an integral part of Europe and former USSR and argued that the aim of state foreign policy should be equal relations with Russia, EU, USA and other countries (Yanukovych, 2010). Importantly, the same rhetorical strategies were further used by both presidents during their presidencies. While Yushchenko in his speech to the European Parliament continued to clearly declare his pro-EU position stating that Ukraine had chosen Europe and was ready to complete necessary reforms in oder to become a member of ,the European family” (Yushchenko, 2005b), Yanukovych argued that Ukraine found itself between „two big monsters - Russia and the EU” (Yanukovych, 2013).

As far as the post-Euromaidan period is concerned, the comparative study of presidential inaugural addresses show significant differences in rhetorical strategies implemented by Petro Poroshenko and Volodymyr Zelensky.

To remind, the nature of relationship between Ukraine and the EU has undergone considerable transformation after the dramatic Euromaidan events. The growing European involvement led to the implementation of European experience in the reform processes in Ukraine, which created favourable conditions for economic and social integration (Leszczenko, 2019, p. 186). Such developments as the adoption of the AA, the abolition of visas for Ukrainian citizens with biometric passports, constitutional amendment introducing the integration with the EU and NATO as a strategic goal for Ukraine illustrated visible progress in the EU-Ukraine cooperation. Meantime, the EU's welcoming of Ukraine's „European aspirations” without a clear declaration to grant a full membership raised questions about the most feasible formula of partnership and the most plausible scenario of European integration processes in Ukraine (Zheltovskyy, 2020, p. 85).

As for the the Europeanization message in the inauguration speech of Poroshenko and Zelensky, the comparison is based on reference to state government, national idea and values. In relation to all three issues mentioned above, President Poroshenko emphasized the significance of European experience on given matters and declared his willingness to use it as an example for Ukraine. Particular attention was paid to the European tradition of local self-government and the need to decentralise Ukrainian system of government. As a matter of fact, the self-government and decentralisation reform was one of the key reforms of Poroshenko presidency that engaged policymakers and civil society actors from Ukraine and the EU (Poroshenko, 2014). 
In his turn, Volodymyr Zelensky chose a different rhetorical strategy addressing the EU theme in his speech. Having stated that „European country begins with each of us”, president Zelensky addressed the issues of values or policy-making without putting emphasis on the EU's experience in given fields. Unlike previous inaugural address, Zelensky's speech did not include such direct reference to the EU regarding the issue of values, state management or development vector either (Zelensky, 2019).

The table below illustrates key words used by both presidents in reference to constituents associated with the concept of Europeanization:

Table 1. Europeanization theme in presidential inaugural addresses

\begin{tabular}{|l|l|l|}
\hline Issue & $\begin{array}{l}\text { Terminology used by Petro } \\
\text { Poroshenko }\end{array}$ & $\begin{array}{l}\text { Terminology used by Volodymyr } \\
\text { Zelensky }\end{array}$ \\
\hline state management & $\begin{array}{l}\text { European democracy as the best } \\
\text { way of state government; } \\
\text { delegation of power from }\end{array}$ & $\begin{array}{l}\text { Each Ukrainian is responsible for } \\
\text { building a prosperous state }\end{array}$ \\
\hline national idea & $\begin{array}{l}\text { European choice as a uniting idea } \\
\text { for all Ukrainians }\end{array}$ & $\begin{array}{l}\text { „to unite and make the impossible } \\
\text { against all odds”; } \\
\text { appeal to Ukrainian diaspora to come } \\
\text { back in order to build state together } \\
\text { based on their knowledge and } \\
\text { expertise }\end{array}$ \\
\hline values & $\begin{array}{l}\text {,ideas of independence, freedom, } \\
\text { dignity, legitimate state, European } \\
\text { integration” }\end{array}$ & $\begin{array}{l}\text { equality before the law, honest and } \\
\text { transparent rules. }\end{array}$ \\
\hline European Union & Europe as Motherland for Ukraine & no direct reference \\
\hline
\end{tabular}

Source: own representation based on the analysis of inaugural addresses delivered by Petro Poroshenko and Volodymyr Zelensky. 
As it is seen in the table, the Europeanization theme was more vivid in the inaugural address of Petro Poroshenko. At the same time, both addresses stressed that the time for positive changes had come and put emphasis on peace, security and unity as key constituents of such changes to happen. In this regard, Tsybulenko and Pakhomenko (2016, p.174) point to the outcomes of the 2015 survey among Ukrainian opinion leaders on their expectations toward the EaP initiative. In fact, it is the weakness of the security component in terms of the EaP that was underlined by $47.7 \%$ of survey's respondents entitled "Important, forgotten or unnecessary?".

Meanwhile, the internal policy issues were addressed by President Poroshenko during his first press conference on 29 December 2014, which turned out to be a platform for critical debate. Among the discussed topics were the improvements in Ukrainian military sector, consolidation of Ukrainian society around the pro-European course of state development, and plans for political solution of the conflict in Donbas. It should be particularly emphasised that the key message on reaching stability in Donbas referred to the need of creating conditions for local elections in accordance with Ukrainian legal system. Moreover, Poroshenko announced that his "mega task" was to make reforms and create ground for economic growth in 2016 that in turn would attract investments in Ukraine (Ukrainska Pravda, 2015).

Overall, due to the chronological limitation of the article focus, the analysis covers mainly the Europeanization ad personam case of Petro Poroshenko. As a matter of fact, selected speeches delivered by Poroshenko vividly illustrate the emphasis on the declaration to integrate with Europe. The issue of European integration was constantly addressed at the EU-Ukraine Summits as well as at other international forums such as Munich Security Conference. To be precise, the final remarks of the speech at the 2015 Munich Security Conference included the accent on such steps as visa-free regime for Ukrainians and closer EU-Ukraine cooperation towards the implementation of reforms. Moreover, the particular accent was put on „entering the European family" as a dream of Ukrainian people (Poroshenko, 2015).

Particular attention should be paid to the EU-EaP Summits addresses that illustrate the evolution of presidential declarations on given matter. On the $2017 \mathrm{EaP}$ summit the presidential address highlighted the Ukrainian expectations as regards custom alliance, association with Schengen zone, energy alliance, and common digital market. Moreover, the speech argued for more Europe in Ukraine and building EaP on the basis of differentiated approach (Poroshenko, 
2017). As it was shown in previous part, this appeal has been repeated by Zelensky team on every occasion.

In reference to Volodymyr Zelensky speech from 22 January 2020 at the World Economic Forum in Davos, it included a brief statement that Ukraine sees its future in Europe. However, the speech sent mixed signals. On the one hand, the Ukrainian president stated that the EU should „take Ukraine into the EU" due to the fact that Ukraine signed the AA and continues maintaining the pro-European course. Furthermore, in accordance with president Zelensky, not only Ukraine but also „the EU should want to engage Ukraine in the EU" (Eurointegration, 2020). Such statement raised important questions about the commitment and expectations toward perspective cooperation from both parts. At the same time, at the level of declarations, the presidential message coincided with the messages of his predecessor stating that Ukraine will become a member of European family (LB.ua, 2020).

Overall, as far as the declarations on the Europeanization processes in Ukraine after the 2019 presidential and parliamentary elections are concerned, it is too early to make conclusions regarding the effects of the process. The 21st EU-Ukraine summit in Kyiv on 8 July 2019 included joint political statements on "the strength of the political and economic ties between the EU and Ukraine". In fact, a general overview of the implementation of the AA demonstrates that the "progress of performance of the scheduled objectives in 2018 increased by 11\% against 2017 and amounted to 52\%" (Consilium.Europa.EU, 2019). In reference to Volodymyr Zelensky who has had the unprecedented victory in both presidential and parliamentary election, one might assume that the success of the Europeanization processes in Ukraine in the upcoming years will greatly depend on his personal position and engagement in given issue.

\section{Conclusions}

In summary, as the above analysis of the EaP Initiatives' impact on the Europeanization processes in Ukraine has demonstrated, a significant progress has been achieved in the institutional dimension of cooperation between the EU and Ukrainian policy-makers as well as in the wider engagement of the civil society into the decision-making process. By introducing effective mechanisms of cooperation between political and civil actors and due to the active position of the latter on the reforming processes in Ukraine, the implementation of the EaP initiatives has led to 
the first fruitful outcomes in transferring European good practices of government on Ukrainian ground.

Particularly, the external Europeanization outcomes are reflected in the reform of decentralisation and local self-government in Ukraine that illustrates the dynamic cooperation between political actors and civil society organisations with active participation of European experts. That said, despite the positive launch of anti-corruption reforms in Ukraine in 2014, the international evaluation of the corruption rate shows rather slow positive dynamics that might be the result of insufficient efforts of Ukrainian authorities directed at overcoming systemic corruption. Undoubtedly, such state of events may undermine the efforts to reform the governmental system and diminish the Europeanization effects.

As for the Europeanization ad personam, the analysis of political discourse on the matter of Ukraine's cooperation with the EU has illustrated a strong pro-European narration in rhetorical strategies of presidents Poroshenko and Zelensky. At the same time, one could notice a change of accents in the messages of current administration. There has been a repeated appeal to the EU to take a more proactive position on the EU membership prospects for Ukraine. Similar message referred to the future format of the EU-Ukraine cooperation in terms of the $\mathrm{EaP}$ and the need to adjust it in accordance with the Ukrainian expectations.

It remains to be seen whether arguments of the Ukrainian policy-makers will lead to the significant change of the EaP cooperation format and introduction of clear incentives and membership prospects for Ukraine. However, due to the dynamic character of geopolitical situation and existing threats in the region, the proactive position and commitment of the EU coupled with its readiness for creative solutions to increase its influence in the region will undoubtedly determine the level of Europeanization in Ukraine in the near future.

In order to be effective, the EaP initiatives must be implemented with the concerted efforts of policy-makers and social actors such as civil society organisations and scholars. They should also involve a process of learning how to work together toward the common goal as a priority task for European and Ukrainian decision-makers. Therefore, undertaken initiatives should be accompanied by the strategic communication campaign and responsible political discourse in order to create a sustainable partnership and favourable ground for the success of Europeanization processes in Ukraine. 
Acknowledgement: The preparation of this article was financed in terms of the Programme „DIALOG” of the Ministry of Science and Higher Education of Poland realised in years 20192021.

\section{References}

1. AGH, A. (2016) The "securitization" of the EaP policy in the EU: the external Europeanization in the wider Europe, Journal of Comparative Politics Vol. 9, No.1, pp. 36-58.

2. BARBURSKA, O. (2019) Stanowisko głównych aktorów zewnętrznych wobec Partnerstwa Wschodniego Unii Europejskiej, Rocznik Instytutu Europy Środkowo-Wschodniej 17, pp. $155-169$.

3. BECK, U., GRANDE, E. (2009), Europa kosmopolityczna, Warszawa.

4. BORZEL, T., (2005), Europeanization: How the European Union Interacts with Its Member States. In: SIMON BULMER, CHRISTIAN LEQUESNE (eds.), The member States of the European Union, New York, pp. 45-76.

5. BUGLAY, N. (2013) Ukrainian-Polish Cooperation at Regional Level in the Context of the European Integration, Central European Papers, 2013/1/2, pp. 81-86.

6. CIANCIARA, A. (2017), Europejska polityka sąsiedztwa w perspektywie konstruktywizmu. Aktorzy, narracje, strategie, Warszawa.

7. COMMITTEE OF THE REGIONS (2009) Opinion of the Committee of the Regions on the role of local and regional authorities within the Eastern Partnership, 25 August. Available from:

http://eur-lex.europa.eu/legalcontent/PL/TXT/?uri=uriserv:OJ.C_2009.200.01.0031.01.POL [Accessed: 30.05.2020].

8. CONSILIUM.EUROPA.EU (2019) EU-Ukraine summit, Kyiv, Ukraine. Available from: https://tiny.pl/tpg9h [Accessed: 30.05.2020].

9. DOMARADZKI S. (2014) The role of NATO and the EU in the Ukrainian Crisis. In:. KLAUS BACHMAN, IGOR LYUBASHENKO (eds.), The Maidan Uprising, Separatism and Foreign Intervention, Ukraine's complex transition, Studies in Political Transition 4, Peter Lang Edition, pp. 267-298.

10. EaP CIVIL SOCIETY FORUM (2019), Declaration of the 11th Annual Assembly of the Eastern Partnership Civil Society Forum (EaP CSF) EaP4EU: Joining forces for a win-win 
partnership, Available from:https://eap-csf.eu/wp-content/uploads/Declaration-of-EaP-CSFAA_final.pdf. [Accessed: 5.06.2020].

11. EaP INDEX 2017 (2018), Available from: https://eap-csf.eu/wp-content/uploads/EaPIndex-2017.pdf. [Accessed: 3.06.2020].

12. EaP 2030 TRENDS (2019), Available from: https://visegradinsight.eu/eap2030/easternpartnership-2030-trends/ [Accessed: 9.09.2020].

13. EEAS.EUROPA.EU (2019) Statement by the Spokesperson on the Ukraine's adoption of the legislation to establish a High Anti-Corruption Court. Available from: https://eeas.europa.eu/delegations/ukraine/49325/node/49325 en. [Accessed: 2.06.2020].

14. EURONEST Parliamentary Assembly Rules of Procedure. Available from: http://www.epgencms.europarl.europa.eu/cmsdata/upload/ac58abd6-f628-4850-83a3ca2812d17922/rules_of_procedure_en.pdf. [Accessed: 2.06.2020].

15. EUROPEAN COMMISSION (2004) Proposal for a Regulation of the European Parliament and of the Council laying down general provisions establishing a European Neighbourhood and Partnership Instrument, 29 September, Brussels. Available from:https://eur-

lex.europa.eu/LexUriServ/LexUriServ.do?uri=COM:2004:0628:FIN:EN:PDF [Accessed: 5.06.2020].

16. EUROPEAN COMMISSION (2006) Regulation No 1082/2006 of the European Parliament and of the Council on a European grouping of territorial cooperation, 5 July. Available from: https:/eur-lex.europa.eu/legalcontent/EN/TXT/?uri=celex\%3A32006R1082. [Accessed: 5.06.2020].

17. EUROPEAN COMMISSION (2012) Proposal for a Regulation of the European Parliament and of the Council, 14 March, Brussels. Available from: https://ec.europa.eu/regional_policy/sources/docoffic/official/regulation/pdf/2014/proposals/r egulation/egtc/egtc proposal en.pdf. [Accessed: 5.06.2020].

18. EUROPEAN COMMISSION (2016) Staff Working Dokument „,Key European action supporting the 2030 Agenda and the Sustainable Development Goals". Available from: https://eur-lex.europa.eu/legal-content/de/TXT/?uri=CELEX:52016SC0390 [Accessed: 5.09.2021]. 
19. EUROPEAN COMMISSION (2020) Joint communication to the European Parliament, the European Council, the Council, the European Economic and Social Committee and the Committee of the Regions, EaP policy beyond 2020, Reinforcing Resilience - an EaP that delivers for all, 18 March, Brussels. Available from: https://eeas.europa.eu/sites/eeas/files/1_en_act_part1_v6.pdf. [Accessed: 4.06.2020].

20. EVROPEISKA PRAVDA (2020) Zelensky u Davos zaproponuvav vziaty Ukrainy v ES zamiast Brytanii, 22 January. [Online]. Evropeiska Pravda. Available from: https://www.eurointegration.com.ua/news/2020/01/22/7105463/. [Accessed: 12.06.2020].

21. GAHLER, M. (2021), Boosting the EU's soft power in Eastern Partnership countries. Available from: https://journals.sagepub.com/doi/full/10.1177/1781685821999847 [Accessed: 12.06.2021].

\section{JOINT DECLARATION OF THE INTERNATIONAL CRIMEA PLATFORM} PARTICIPANTS (2021). Available from: https://mfa.gov.ua/en/news/joint-declarationinternational-crimea-platform-participants [Accessed: 4.09.2021].

23. KOROSTELEVA, E. (2013) Evaluating the Role of Partnership in the European Neighbourhood Policy: the Eastern Neighbourhood, Eastern Journal of European Studies, Vol.4,Issue 2, December 2013, pp. 7-32.

24. KRUGLASHOV, A. (2020), Eastern Partnership vis-à-vis challenges and doubts, Studia i analizy nauk o polityce No1/2020, pp. 55-68.

25. KULEBA, D. (2021), Ukraine, Georgia and Moldova establish the Association Trio. Available from: https://www.kmu.gov.ua/en/news/dmitro-kuleba-ukrayina-gruziya-tamoldova-zapochatkuvali-asocijovane-trio.

26. LAVENEX, S. (2007) The external face of Europeanization: third countries and international organisations. In: ANDREAS ETTE/ THOMAS FAIST (eds.), The Europeanisation of Immigration Policy, London: Palgrave 2007, pp. 246-267.

27. LB.UA (2020) Pobudova Yevropy ne mode buty zkavershenoju bez Ukrainy, 16 May. [Online] $\underline{\text { lb.ua. }}$

Available from:https://ukr.lb.ua/news/2020/05/16/457671_pobudova_ievropi_mozhe_vvazhatisya.html ). [Accessed: 10.06.2020].

28. LESZCZENKO, L. (2019), Ukraina - pożegnanie wielowektorowości. Europeizacja polityki zagranicznej i bezpieczeństwa. In: LARYSA LESZCZENKO, HELENA GIEBIEŃ, 
ANNA JAGIEŁŁO-SZOSTAK, JAROSŁAW JARZĄBEK, ELŻBIETA SZYSZLAK, TOMASZ SZYSZLAK (eds.), Pogranicza cywilizacji. Wpływ dylematów tożsamościowych na politykę zagraniczna i bezpieczeństwa wybranych państw Europy Środkowo-Wschodniej, Warszawa.

29. LOVITT, J. (ed.) (2018) EaP Index 2017. Available from: https://eap-csf.eu/wpcontent/uploads/EaP-Index-2017.pdf. [Accessed: 7.06.2020].

30. OLSEN, J. (2002) The Many Faces of Europeanization, Journal of Common Market Studies, Vol. 40, No. 5, pp.921-952.

31. POROSHENKO, P. (2014) Inaugural presidential address of Petro Poroshenko. Available from: http://euromaidanpress.com/2014/06/07/petro-poroshenkos-speech-at-the-inaugurationfull-text/. [Accessed: 12.06.2020].

32. POROSHENKO, P. (2015) Speech by the President of Ukraine Petro Poroshenko at the Munich Security Conference. Available from: https://edinburgh.mfa.gov.ua/news/32867speech-by-the-president-of-ukraine-petro-poroshenko-at-the-munich-securityconference).[Accessed: 12.06.2020].

33. POROSHENKO, P. (2017) Speech by President of Ukraine Petro Poroshenko at the 2017 EaP Summit. Available from: https://www.eurointegration.com.ua/articles/2017/11/24/7074149/. [Accessed: 12.06.2020]. 34. RICE, C. (2018) Democracy, Kharkiv: Hemiro Ltt.

35. RUSZKOWSKI, J. (2019) Europeizacja. Analiza oddziatywania Unii Europejskiej, Warszawa: Difin.

36. TSYBULENKO E., PAKHOMENKO S. (2016) The Ukrainian Crisis as a Challenge for the Eastern Partnership. In: KERIKMAE T., CHOCHIA A. (eds.) Political and Legal Perspectives of the EU EaP Policy, Springer, pp. 167-181.

37. TYMANOWSKI J.(2014) Ukraina między Wschodem a Zachodem, Warszawa: Warsaw University Press.

38. TACZYŃSKA, J.(2013) Wspótpraca polskich jednostek samorzadu terytorialnego z władzami regionalnymi i lokalnymi oraz innymi podmiotami z państw objętych inicjatywa Partnerstwa Wschodniego.

Available from:https://www.umww.pl/attachments/article/36935/Partnerstwo\%20Wschodnie\%20\%20Samorzady.pdf. [Accessed: 25.05.2020]. 
39. TOSIEK P. (2018) Member State in the Decision-Making System of the European Union. The Example of Poland, Lublin UMCS.

40. TOSIEK P. (2012) Challenges of Europeanization in New EU Member States. In: CHAŁUPCZAK H. et al. (eds.) European Integration. Models, Challenges, Perspectives, Zamość: Officina Simonidis, pp.169-185.

41. TRANSPARENCY INTERNATIONAL (2019) Transparency International. Corruption Perception Index 2018. [Online] Transparency International. Available from: https://tiny.pl/tpgem. [Accessed: 1.06.2020].

42. UKRAINSKA PRAVDA (2014) Press conference of President Poroshenko from 29 December 2014, 29 December. [Online] Ukrainska Pravda. Available from: http://www.pravda.com.ua/photo-video/2014/12/29/7053739/ . [Accessed: 12.06.2020].

43. VOX UKRAINE (2018) Antykorupcijna reforma: chogo naspravdi dosiagla Ukraine. [Online] Vox Ukraine. Available from: https://tiny.pl/tpgcx. [Accessed: 14.06.2020]. 44. YANUKOVYCH, V. (2010) Inaugural presidential address of Viktor Yanukovych. Available from: http://web.archive.org/web/20100228163643/http://www.president.gov.ua/news/16600.html. [Accessed: 12.06.2020].

45. YANUKOVYCH, V. (2013) Ukrayina vpevneno yde shlyahom yevrointegratsiyi. Availble from: https://yes-ukraine.org/ua/news/ukrayina-vpevneno-yde-shlyahom-yevrointegratsiyiviktor-yanukovich. [Accessed: 12.06.2020].

46. YUSHCHENKO, V. (2005) Inaugural presidential address of Viktor Yushchenko. Available from: http://www.ukrweekly.com/old/archive/2005/050523.shtml). [Accessed: 12.06.2020].

47. YUSHCHENKO, V. (2005) Ukraine's future is in the EU. Available from: https://www.europarl.europa.eu/sides/getDoc.do?pubRef=-//EP//TEXT+PRESS+DN20050223-1+0+DOC+XML+V0//EN. [Accessed: 12.06.2020].

48. ZELENSKY, V. (2019) Inaugural presidential address of Volodymyr Zelensky. Available from: https://www.president.gov.ua/en/news/inavguracijna-promova-prezidenta-ukrayinivolodimira-zelensk-55489. [Accessed: 12.06.2020].

49. ZHELTOVSKYY, V. (2019) Self-governance in Ukraine: Origin, Evolution and Perspectives, Pultusk: Aspra JR. 
50. ZHELTOVSKYY, V. (2016) The EaP and its Impact on Self-governance Reform in Ukraine, CES Working Papers vol.8(3), issue 3, pp. 550-571.

51.ZHELTOVSKYY, V. (2020) European integration processes in Post-Euromaidan

Ukraine: in Search for Scenarios, On-line Journal Modelling the New Europe, No. 32/2020, pp. 72-93. 